\title{
Teknik Konsentrasi Formol Eter untuk Mendiagnosa Parasit Usus
}

\section{Formol Ether Concentration to Diagnose Intestinal Parasites}

\author{
Elva Susanty ${ }^{1 *}$ \\ ${ }^{1}$ KJF Parasitologi Fakultas Kedokteran Universitas Riau
}

\begin{abstract}
ABSTRAK
Infeksi parasit usus merupakan penyakit endemik yang menyebabkan masalah kesehatan di negara berkembang seperti Indonesia. Diagnosa parasit usus memerlukan teknik pemeriksaan yang sensitif dan biaya murah. Teknik konsentrasi formol eter (formol eter concentration/FEC) merupakan salah satu teknik pemeriksaan dengan sampel feses untuk mendeteksi parasit usus dengan prinsip sedimentasi. Tehnik ini merupakan salah satu tehnik yang ekonomis, mudah dilakukan, dan meningkatkan jumlah penemuan parasit usus karena dapat memisahkan debris dari feses. Tujuan: Mengetahui teknik konsentrasi formol eter dalam mendiagnosa parasit usus. Tinjauan Pustaka: Prevalensi infeksi parasit usus masih cukup tinggi di negara berkembang akibat kurangnya sanitasi dan buruknya higiene, sehingga diperlukan suatu teknik pemeriksaan yang bisa mendeteksi kista protozoa, larva, dan telur cacing. Teknik FEC menggunakan formalin $10 \%$ dalam air sebagai penstabil dan eter sebagai pelarut. Teknik FEC tidak merusak organisme dalam sampel feses, dapat mengetahui parasit usus dengan sampel feses sedikit, dan ekonomis. Beberapa penelitian menunjukkan bahwa teknik FEC lebih baik daripada teknik direct wet mount dalam mendiagnosa parasit usus. Simpulan: Teknik FEC merupakan salah satu teknik pemeriksaan yang sensitif dan ekonomis dan dapat digunakan sebagai pilihan untuk mendiagnosa parasit usus.
\end{abstract}

Kata Kunci: parasit usus, sedimentasi, teknik diagnosa, teknik konsentrasi formol eter

\begin{abstract}
Intestinal parasites infection are an endemic disease and still major public health problems in developing countries such as Indonesia. Diagnosis of intestinal parasites requires a sensitive examination technique and low cost. Formol ether concentration (FEC) technique is one of examination technique with stool sample to detect intestinal parasite with sedimentation principle. This technique is one technique which economical, simple, and increase the number of discovery of intestinal parasites due separate debris from the feces. Aim: To know the concentration of formol ether technique for diagnosing intestinal parasites. Literature Review: The prevalence of intestinal parasite infection is still high in developing countries due to lack of sanitation and poor hygiene, requiring an examination technique that can detect protozoan cysts, larvae, and worm eggs. The FEC technique uses formalin $10 \%$ in water as a stabilizer and an ether as a solvent. FEC techniques do not damage organisms in feces samples, can know intestinal parasites with little fecal samples, and are economical. Some studies show that FEC techniques are better than direct wet mount techniques in diagnosing intestinal parasites. Conclusion: The FEC technique is one of the examination techniques which sensitive and economical and can be used as an option for diagnosing intestinal parasites
\end{abstract}

Keywords: diagnostic technique, formol ether concentration technique, intestinal parasite, sedimentation

*Korespondensi: Elva Susanty, email: kaylaelva007@gmail.com

Artikel info: Online published first 25 April 2018; Received 4 Februari 2018: Accepted 11 April 2018

DOI: https://doi.org/10.26891/jkm.v1i2.2018.125-129

Copyright @ 2018 Elva Susanty. This is an open access article distributed under the terms of the Creative Commons Attribution-NonCommercial 4.0 International License (http://creativecommons.org/licenses/by-nc/4.0/), which permits unrestricted non-commercial use, distribution, and reproduction in any medium, provided the original author and source are properly cited. 
Infeksi parasit yang disebabkan oleh cacing usus dan protozoa merupakan infeksi dengan prevalensi tertinggi di negara berkembang, sedangkan protozoa lebih sering menyebabkan infeksi di saluran pencernaan di negara maju. ${ }^{1}$ Infeksi parasit usus tersebut dapat menimbulkan morbiditas dan mortalitas cukup tinggi di negara berkembang. ${ }^{2}$ Diperkirakan terdapat 3,5 milyar orang terinfeksi parasit usus dan 450 juta orang diantaranya menjadi sakit karena parasit usus. ${ }^{3}$ Penyakit cacing usus disebabkan karena kemiskinan, kurangnya sanitasi, air bersih, dan personal higiene ${ }^{1,2}$ sedangkan terjadinya penyebaran infeksi protozoa di negara berkembang paling sering karena terkontaminasi feses sebagai hasil buruknya saluran pembuangan air limbah dan kualitas air. ${ }^{1}$

Infeksi beberapa parasit usus (poliparasit) sering terjadi di negara berkembang ${ }^{4}$ dan adanya perbedaan infeksi parasit tergantung dari faktor lingkungan, sosial, dan ekonomi ${ }^{3}$ oleh karena itu untuk pencegahan infeksi poliparasit memerlukan alat tes diagnostik atau teknik pemeriksaan yang sensitif, mudah dilakukan, dan dapat mendeteksi infeksi beberapa parasit usus yang terjadi secara bersamaan. ${ }^{4}$

Diagnosa, pengobatan, dan pencegahan parasit usus sudah ada sejak lama. Diagnosa laboratorium dan pengobatan parasit usus tidak berubah banyak, dan metode mikroskopis masih dapat digunakan dan masih menjadi pilihan untuk menegakkan diagnosa infeksi parasit usus. ${ }^{1}$ Diagnosa laboratorium parasit usus merupakan suatu proses yang digunakan untuk mencari penyebab penyakit dan mengidentifikasi bagian-bagian parasit usus atau bentuk stadium hidup parasit usus seperti: telur, kista, trofozoit, atau larva., ${ }^{5,6}$ Pemeriksaan telur cacing, dan parasit secara mikroskopis merupakan metode tradisional untuk mendeteksi parasit dengan sampel feses dan membutuhkan keahlian tinggi untuk interprestasi tinggi dalam mendeteksi parasit usus. ${ }^{7}$ Deteksi parasit usus dengan pemeriksaan mikroskopis merupakan teknik laboratorium yang baik dan banyak digunakan untuk pemeriksaan feses dengan berbagai jenis prosedur teknik pemeriksaan. ${ }^{8}$

\section{METODE}

Penulisan artikel ini berdasarkan studi kepustakaan, yang membahas tentang prinsip, alat, bahan, dan cara kerja serta kelebihan dan kekurangan teknik konsentrasi formol eter dalam mendiagnosa parasit usus.

\section{HASIL DAN PEMBAHASAN}

\section{Teknik Konsentrasi untuk Parasit Usus}

Ada beberapa macam teknik pemeriksaan untuk mendiagnosa parasit usus, diantaranya yaitu: teknik konsentrasi, Kato-Katz, direct wet mount, ${ }^{2,9}$ polymerase chain reaction (PCR), dan direct fluorescent antibody. ${ }^{10}$ Pemilihan teknik yang digunakan untuk pemeriksaan feses rutin sebaiknya adalah tehnik pemeriksaan yang bisa digunakan untuk mendeteksi kista protozoa dan telur cacing. ${ }^{11}$ Teknik konsentrasi merupakan salah satu teknik untuk mengetahui ada tidaknya kista protozoa dan telur cacing dalam sampel feses. ${ }^{2}$ Teknik konsentrasi merupakan teknik pemeriksaan yang sensitif, mudah dilakukan, dan ekonomis. ${ }^{10}$ Organisme yang dapat dideteksi dengan menggunakan prosedur konsentrasi diantaranya yaitu: telur cacing usus, larva, kista Giardia lamblia, Entamoeba coli, Endolimax nana, Blastocystis hominis, dan lodamoeba butschii, dan ookista Isospora belli, dan lain-lain. ${ }^{12}$

Teknik konsentrasi terdiri dari 2 yaitu: teknik sedimentasi (pengendapan); telur dan kista berada di dasar sediaan, dan teknik flotasi atau pengapungan; telur dan kista berada terapung pada permukaan karena adanya gravitasi. ${ }^{13}$ Beberapa teknik sedimentasi diantaranya yaitu: zinc sulphate, formol eter concentration (FEC) atau teknik konsentrasi formol eter, dan modifikasi konsentrasi formol eter. ${ }^{2,12}$ Prinsip teknik sedimentasi adalah parasit yang lebih berat berada di dasar sebagai hasil dari gravitasi atau sentrifugasi. ${ }^{11}$ Teknik konsentrasi bukan saja memisahkan debris dari sampel feses tetapi dapat meningkatkan jumlah parasit usus di endapan yang terbentuk dan membuat parasit usus lebih terlihat karena hilangnya debris di sampel feses. ${ }^{6}$ Teknik konsentrasi diperkenalkan oleh Ritchie sejak tahun 1948 kemudian dikembangkan oleh Ridley dan Hawgood pada tahun 1956 dan disederhanakan oleh Ridley dan Allen pada tahun 1970 dengan menggunakan formalin 10\% dalam air sebagai penstabil (fixative), eter sebagai solvent (pelarut) untuk menyingkirkan debris dan lemak yang ada di feses, diikuti dengan filtrasi melalui saringan dengan ukuran lubang 425 mikron dan disentrifugasi dengan kecepatan 3.000 rpm selama 1 menit sehingga telur, kista, dan larva di sedimen pada dasar tabung sentifugasi. ${ }^{14,15}$

Teknik FEC biasanya digunakan untuk mendeteksi telur cacing dan kista protozoa dari sampel feses berlemak ${ }^{4,5}$ dan dapat meningkatkan penemuan kista protozoa, larva, dan telur cacing. ${ }^{2}$ Ritchie 
menemukan bahwa teknik FEC lebih baik dari pada teknik direct smear dan beberapa teknik sedimentasi lain untuk menemukan parasit atau telur cacing dan kista protozoa. Sejak saat itu, teknik FEC berkembang dengan berbagai modifikasi dan merupakan salah satu teknik yang sering digunakan untuk mendeteksi telur cacing dan kista protozoa ${ }^{14}$ serta merupakan salah satu metode yang biayanya murah. $^{12}$

\section{Prinsip Teknik FEC}

Prinsip teknik FEC dalam larutan formaldehid, yang mengawetkan setiap parasit yang ada dalam spesimen. Residu berupa gumpalan kasar dipisahkan secara filtrasi. Elemen lemak dalam suspensi feses dipisahkan secara ekstraksi menggunakan eter (atau etil asetat), diikuti dengan sentrifugasi, yang mengendapkan setiap parasit yang ada dalam spesimen. ${ }^{16}$ Kecepatan sentrifugasi teknik FEC bisa dilakukan dengan kecepatan 2.000 atau $3.000 \mathrm{rpm}$ dengan variasi waktu kecepatan seperti 1 menit dan 3 menit 14,16 sedangkan volume sampel feses yang digunakan 1-2 gram. ${ }^{5}$ Teknik FEC Ridley Allen menggunakan kecepatan sentrifugasi $3.000 \mathrm{rpm}$ selama 1 menit tetapi Manser et al (2016), ${ }^{14}$ menunjukkan bahwa sebaiknya sentrifugasi dilakukan dengan kecepatan 3.000 rpm selama 3 menit dengan menggunakan 1 gram feses karena dapat meningkatkan hasil penemuan jumlah telur, kista protozoa, dan larva.

Endris et al (2013), ${ }^{17}$ menunjukkan bahwa teknik FEC lebih baik dalam mendeteksi telur hookworm dibandingkan dengan teknik Kato-Katz karena telur hookworm bisa rusak karena gliserin yang digunakan pada teknik Kato-Katz, feses terlalu sedikit, dan apabila sampel feses lama diperiksa. Sensitivitas FEC dapat rendah disebabkan karena kemungkinan telur tidak berada di slaid. ${ }^{18}$ Taye, ${ }^{19}$ menunjukkan bahwa diagnosa infeksi cacing dengan menggunakan metode FEC memberikan hasil positif lebih tinggi $(73,5 \%)$ dibandingkan dengan menggunakan metode Kato-Katz (40,7\%). Teknik FEC dan direct smear memiliki keefektifan sama dalam mendeteksi Giardia lamblia, tetapi teknik FEC lebih baik dalam mendeteksi kista sedangkan teknik direct smear lebih baik dalam mendeteksi trofozoit. ${ }^{10}$ Venkatesh et $a l^{3}$ menunjukkan bahwa sensitivitas FEC lebih tinggi dibandingkan dengan zinc sulphate centrifugal flotation dan direct wet mount $(66 \%, 56 \%, 36 \%)$.

\section{Alat, Bahan, dan Cara Kerja}

Alat, bahan, dan cara kerja untuk melakukan teknik FEC yaitu: ${ }^{16}$

1. Mikroskop

2. Kaca objek

3. Penutup kaca objek

4. Centrifuge

5. Tabung reaksi

6. Rak tabung reaksi

7. Tabung centrifuge

8. Aplikator yang terbuat dari kayu

9. Penyaring-kawat, terbuat dari kuningan, dengan 40 lubang $(425 \mathrm{llm})$, diameter $7,2 \mathrm{~cm}$ (supaya tidak terlalu mahal, dapat juga digunakan saringan-kopi yang terbuat dari nilon)

10. Cawan atau gelas piala kecil, terbuat dari porselen atau logam tahan-karat

11. Pipet Pasteur

12. Larutan formalin $10 \% \quad(100 \mathrm{ml}$ larutan formaldehid $37 \%$ dalam $900 \mathrm{ml}$ air suling).

13. Eter atau etil asetat.

Cara Kerja

1. Dengan aplikator, ambil sedikit (kira-kira 0,5 g) feses pada permukaan dan bagian dalam spesimen feses.

2. Masukkan sampel ke dalam tabung centrifuge yang berisi $7 \mathrm{ml}$ formalin $10 \%$.

3. Emulsikan feses dalam formalin, saring, dan pindahkan ke dalam cawan.

4. Bersihkan penyaring (dengan air bersabun) dan buang residu yang menggumpal.

5. Pindahkan filtrat ke dalam tabung reaksi besar. Tambahkan $3 \mathrm{ml}$ eter (atau etil asetat).

6. Sumbat tabung dan kocok hingga isinya tercampur merata.

7. Pindahkan kembali hasil suspensi ke tabung centrifuge dan lakukan sentrifugasi pada $2000 \mathrm{~g}$ selama 1 menit.

8. Bersihkan gumpalan lemak menggunakan aplikator dan buang supematan dengan cara membalik tabung secara cepat.

9. Biarkan cairan yang tersisa di dinding tabung mengalir memicu endapan. Selanjutnya, kocok hingga merata. Dengan pipet, pindahkan setetes cairan tersebut ke atas kaca objek dan tutup dengari penutup kaca objek.

10. Gunakan objektif $x 10$ dan $\times 40$ untuk mengamati telur dan kista dalam keseluruhan lapangan pandang preparat pada penutup kaca objek tersebut. 


\section{Kelebihan dan Kekurangan Teknik FEC}

Teknik FEC memiliki kelebihan dan kekurangan. Beberapa kelebihan teknik FEC yaitu:

- Tidak merusak organisme yang terdapat di feses.

- Mengetahui ada tidaknya telur trematoda seperti Schistosoma spp dan telur trematoda lain yang mempunyai operculum. ${ }^{12}$

- Waktu dilakukan pemeriksaan sampel feses bisa lebih lama (beberapa jam atau beberapa hari) setelah sampel dikonsentrasikan.

- Penyimpanan feses dan pemeriksaan feses bisa lebih lama setelah feses dicampur dengan formalin. ${ }^{10}$

- Dapat mendeteksi parasit usus dalam jumlah sedikit, yang mungkin tidak bisa dilakukan dengan tehnik direct wet mount. ${ }^{12}$

- Eter dipakai sebagai pengekstrak debris dan lemak dari feses, dan meninggalkan parasit pada dasar suspensi. ${ }^{20}$

- Metode FEC lebih berhasil dalam mendeteksi infeksi ringan dan beberapa penelitian menunjukkan adanya peningkatan jumlah parasit yang terdeteksi dengan menggunakan metode konsentrasi.

- $\quad$ Biayanya murah. ${ }^{12}$

- Memiliki sedikit risiko untuk terinfeksi bakteri atau virus karena bakteri dan virus tidak dapat bertahan saat proses konsentrasi dilakukan. ${ }^{10}$

Kekurangan teknik FEC yaitu:

- Proses tehnik FEC lebih rumit dibandingkan dengan tehnik flotasi, memerlukan waktu lebih lama untuk pendeteksian. ${ }^{21}$

- Jika parasit dalam stadium trofozoit, maka parasit tersebut dapat rusak. ${ }^{10}$

\section{DAFTAR PUSTAKA}

1. Haque R. Human intestinal parasites. J Health Popul Nutr. 2007;24(4):387-91.

2. Amin HA, Ali SA. Evaluation of different techniques of stool examination for intestinal parasitic infections in Sulaimani City - Iraq. Int. J. Curr. Microbiol. App.Sci. 2015;4(5):991-96.

3. Venkatesh BMS, Rao SR, Vivekanand N, Shanker BM. A comparative study of concentration techniques for detection of intestinal parasitic infections - to evaluate the prevalence and to identify a better method of concentration technique at aTribal Tertiary Care Hospital. Journal of Dental and Medical Science. 2016;15(7):42-6.

4. Becker SL, Lohourignon LK, Speich B, Rinaldi L, Knopp $\mathrm{S}$, Goran KE, et al. Comparison of the FLOTAC-400 dual technique and the formalin ether concentration technique for diagnosis of human intestinal protozoon infection. J. Clin. Microbiol. 2011;9(6):2183-90.
- $\quad$ Dietil eter, salah satu komponen penting dalam FEC, mudah terbakar, mudah menguap, dapat meledak dan menghasilkan peroksida ketika terpapar ringan, dapat menimbulkan mutasi gen ketika terhirup atau terserap melalui kulit. ${ }^{20}$

- Mengiritasi saluran pernafasan dan dapat menyebabkan gangguan kardiovaskular.

- Eter mungkin bisa saja menyebabkan mutagen, apabila terhirup atau terserap melalui kulit menimbulkan gangguan kesehatan neurotoksisitas atau kanker. ${ }^{22}$

Beberapa zat kimia lain telah dievaluasi untuk mengganti dietil eter seperti etil asetat, aseton, maupun gasolin. ${ }^{20}$ Beberapa laporan menyebutkan bahwa etil asetat cocok sebagai pengganti eter ataupun aseton ${ }^{11}$ karena tidak terlalu mudah terbakar. ${ }^{16}$

\section{SIMPULAN}

Teknik FEC dapat digunakan sebagai pilihan untuk mendeteksi kista protozoa, larva, dan telur cacing. Teknik FEC memiliki hasil yang lebih baik untuk mendeteksi hookworm dibandingkan dengan teknik Kato-Katz. Teknik FEC lebih baik bila dibandingkan dengan teknik direct wet mount. Eter yang digunakan dalam teknik FEC dapat diganti dengan etil asetat. Kecepatan sentrifugasi yang dianjurkan dalam teknik FEC adalah 3.000 rpm selama 3 menit.

\section{KONFLIK KEPENTINGAN}

Tidak ada

5. Balakrishna J, Venkateswarlu, Bai K, Saheb HS Comparison of modified 1\% Potassium Hydroxide Formol-Ether concentration technique with direct wet mount preparation and standard formol-ether concentration technique in stool. J.Pharm. Sci. \& Res. 2013;5(7):147-49.

6. Kassa D, Mengestie A, Ayalew N, Belaynew A, Mebrie $\mathrm{Z}$, Metadel T. A Review on diagnostic techniques in veterinary helminthlogy. Nat Sci. 2016;14(7):109118]. ISSN 1545-0740 (print); ISSN 2375-7167 (online). http://www.sciencepub.net/nature. 15. doi:10.7537/marsnsj140716.15.

7. McHardy $\mathrm{IH}, \mathrm{Wu} \mathrm{M}$, Cohen RS, Couturier MR, Humpries RM. Detection of Intestinal Protozoa in the Clinical Laboratory. Journal of Microbiology. 2014;52(3):712-20.

8. Pakdad K, Nasab SD, Damraj FA, Ahmadi NA. Comparing the efficiency of four diagnostic concentration techniques performed on the same 
group of intestinal parasites. Alex J Med. 2017. Available

https://doi.org/10.1016/j.ajme.2017.11.005.

9. Nikolay B, Brooker SJ, Pullan RL. Sensitivity of diagnostic test for human soil-transmitted helminth infections: a meta-analysis in the absence of a true gold standard. Int J Parasitol. 2014;44(11):765-74.

10. Oguoma V, Ekwunife $C$. The need for a better method: comparison of direct smear and formolether concentration techniques in diagnosing intestinal parasites. The internet journal of tropical. 2006;3(2):1-6.

11. Frische TR, Pritt BS. Medical Parasitology. Dalam: McPherson RA, Pincus MR. edisi ke-23. Henry's Clinical Diagnosis and Management by Laboratory Methods. St. Louis, Missouri: Elsevier, 2017.Chapter 63, 1231-83.

12. Parameshwarappa KD, Chandrakanth C., Sunil B. The prevalence of intestinal parasitic infestations and the evaluation of different concentration techniques of the stool examination. Journal of Clinical and Diagnostic Research. 2012;6(7):1188-91.

13. Frische TR, Pritt BS. Medical Parasitology. Dalam: McPherson RA (penyunting), Pincus MR (Penyunting). Edisi ke-23. Henry's Clinical Diagnosis and Management by Laboratory Methods, St. Louis, Missouri: Elsevier, 2017.Chapter 63, 1231-1283.e3.

14. Manser MM, Saez ACS, Chiodini PL. Faecal parasitology: concentration methodology needs to be better standardised. PLoS Negl Trop Dis. 2016;10(4):1-16.

15. Sato C, Rai SK, Uga S. Re-evaluation of the formalinether sedimentation method for the improvement of parasites egg recovery efficiency. Nepal Med Coll. 2014;16(1):20-25.

16. World Health Organization (WHO). Manual of Basic Techniques for a Health Laboratory. Alih bahasa: Chairlan., Lestari Estu. Editor edisi Bahasa Indonesia: Albertus Agung Mahode. Pedoman Teknik Dasar untuk Laboratorium Kesehatan. edisi ke 2. Penerbit Buku Kedokteran EGC, Jakarta;2011. p. 150-52.

17. Endris $\mathbf{M}$, Tekeste $Z$, Lemma W, Kassu A. Comparison of the Kato-Katz, Wet Mount, and Formol-Ether concentration diagnostic techniques for intestinal helminth infections in Ethiopia. ISRN. Parasitology. 2013, Article ID 180439, 5 pages http://dx.doi.org/10.5402/2013/180439.

18. Lier T, Simonsen GS, Wang T, Lu D, Haukland HH, et al. Low sensitivity of the Formol-Ethyl Acetate sedimentation concentration technique in lowIntensity Schistosoma japonicum infections. PLoS Negl Trop Dis. 2009;3(2):e386. doi: 10.1371/journal.pntd.0000386.

19. Taye, S. Comparison of Kato-Katz and Formol Ether Concentration methods for the diagnosis of intestinal helmintic infection among school children of Wonji Shoa town, Eastern Ethiopia: a school based cross sectional study. American Journal of Health Research. 2014;2(5):271-74.

20. Hussien M, Alamin EA. A comparison between the efficiency of formal gasoline concentration technique and other techniques used for the detection of intestinal parasites. International Journal of Preclinical \& Pharmaceutical Research. 2015;6(2):91-4.
21. Dryden MW, Payne PA. Fecal examination techniques. NAVC Clinician's Brief. 2010:13-16.

22. Moges $F$, Belyhun $Y$, Tiruneh M, Kebede $Y$, Mulu A, et al. Comparison of formol-acetone concentration method with that of the direct iodine preparation and formol-ether concentration methods for examination of stool parasites. Ethiop. J. Health Dev. 2010;24(2):148-51. 